\title{
Experience in conducting field tests of metal structural constructions of coatings of the "BrSTU"
}

\author{
Mikalai Shalabyta ${ }^{1, *}$, Andrei Shuryn ${ }^{1}$, Tatsiana Shalabyta $^{1}$ and Viacheslav Dragan ${ }^{1}$ \\ ${ }^{1}$ Brest State Technical University, 224017, Moskovskaya 267, Brest, Belarus
}

\begin{abstract}
There are quite often statically complex structures, the reliability of theoretical calculations of which needs experimental verification in the world practice of design and construction. Studies of building structures functioning can be full-scale or carried out on their models in laboratory conditions depending on the goals set. Full-scale tests of building structures are more expensive, therefore, their implementation requires a special approach and justification.

However, to check the operation of complex, critical structures which primarily include metal spatial large-span structures of coatings of buildings and structures especially those used for the first time to assess their bearing capacity, to establish the degree of participation in the construction of each of the elements, to study the operation of individual new nodal elements etc., only full-scale tests are required.
\end{abstract}

Key words: metal structural constructions, nodal connection, numerical model, stress-strain field tests.

\section{Introduction}

In accordance with the requirements of EN 1990 [1], one of the methods in the design of complex building structures is design based on the test results while depending on the goals set they can be carried out either on their models or full-scale tests of built objects. Fullscale tests of building structures are more expensive than tests on models, however, to check the operation of unique structures used for the first time, to assess their bearing capacity, to establish the degree of participation in the work of the structure of other elements (girders, etc.), to study the operation of separate elements is possible only with this type of test.

Considerable experience has been accumulated in the design and construction of buildings and structures that are unique in the architectural and structural terms in world practice. In the overwhelming majority of cases, metal spatial structures are used when designing such objects. The development of systems of spatial structures is based on the fundamental architectural and structural prerequisites: a single unified range of elements with maximum compositional capabilities; use of rolled profiles with optimal shape; use of high-

\footnotetext{
* Corresponding author: nnshalobyta@mail.ru
} 
strength materials; complete industrialization of production based on the use of highperformance automatic equipment, casting, stamping, etc .; compactness of system elements and the possibility of their transportation by any means of transport; high reliability, quick assembly and installation of elements, including large-block assembly; wide possibilities of volumetric-spatial composition in the form of an almost unlimited variety of constructive forms based on a limited set of initial types of elements. Possessing the abovementioned features, spatial metal rod structures with rational manufacturability and low material consumption, provide the possibility of wide unification of structural elements, organize in-line production of a limited nomenclature of the same type of elements, from which a wide variety of spatial structures with high architectural and aesthetic properties can be created.

A number of architecturally unique and structurally complex constructions were designed and built using a new metal structural structure developed at the Brest State Technical University, called the "BrSTU" system in the new century in the Republic of Belarus, they are the covering of the summer amphitheater in Vitebsk, covering of the amphitheater in the park Victories in Molodechno, the dome of the National Olympic Committee of the Republic of Belarus, etc. Most of the designed and built objects have statically complex structures of spatial coverings, the reliability of the calculation of which needed experimental verification not only of separate elements (primarily of the nodal connection), but also full-scale tests of the entire structure [2 ... 8].

The structural design of the "BrSTU" system has a structurally unique nodal element which is made in the form of a hollow sphere with holes in the wall into which through special rigid washers with spherical surfaces facing the sphere, bolts are installed to connect with rod elements. High-strength bolts designed to connect the rod elements of the structural plate they are passed from the side of the ball cavity through the holes and have the ability to freely rotate around their own axis which ensures free assembly of the structure lattice elements. The sphere is made of two hemispheres, obtained by hot pressing from sheet metal and joined by a butt seam with cutting edges. Hemispheres are made by hot pressing from sheet metal with milling of diametrical edges. In more detail, the design solution of the key elements of the "BrSTU" system is described in [3, 4, 5, 8].

Brest State Technical University has accumulated vast experience in carrying out field tests of structural constructions. This article discusses only a few (significant), of more than three dozen structural coatings designed and tested under the guidance of Professor of the Department of Building Dragan V.I. with nodal connections of the "BrSTU" system, as well as the goals and objectives of carrying out field tests [ $3 \ldots 8$. 8 .

\section{Methods}

The analytical determination of forces and displacements in the elements of the structural construction of the "BrSTU" system for most of the designed objects was carried out using the "LIRA-Windows" program [3, 5, 6, 8]. The unit of the structural construction of the "BrSTU" system refers to complex combined joints in which each component makes a certain contribution to the overall stress-strain state of not only the nodal connection but also the structure as a whole. In this regard, structural calculations were performed in several stages. The first and second stages included calculations of the spatial structure of the structural slab taking into account the effect on it of static design loads and loads corresponding to full-scale tests, respectively. The calculation was carried out for a numerical model in which all the bar elements are hinged at the nodes taking into account the elastic stage of the construction material, i.e. as a hinge-rod system without taking into account the elastic 
compliance of the nodal elements. As a result of the static calculation, the maximum design forces that the elements of the structural slab are perceived were determined, their sections were selected with the appropriate geometric and stiffness characteristics and the expected values of the forces in the stubble elements of the structure and the movement of nodes at the points designated for experimental research were estimated.

At the third stage, the actual work of the nodal elements of the structural construction was simulated under the action of a static test load in the elastic stage of the work of the structure material. The flexibility of the structural slab nodes was taken into account by a decrease in the stiffness characteristics of the structure rods.

The last stage included the evaluation of the obtained numerical data on the stress-strain state of the structural slab by means of field tests under the action of a static test load.

\section{Results and Discussion}

Roof construction of the Summer Theater in the Park of Culture and Leisure in Brest. The structural construction of the roof was designed and built in 2006 and is made in the form of a cantilever roof slab with plan dimensions of $22.5 \times 18 \mathrm{~m}$ with an orthogonal grid of chords, the nodes of the lower grid of which are shifted relative to the nodes of the upper one by half the size of the cell. The mesh cell for the upper and lower chords is $1.5 \times 1.5 \mathrm{~m}$ and the height along the axes of the chords is $1.06 \mathrm{~m}$. This object is the first in the practice of using a fundamentally new nodal element of the "BrSTU" system. The structural slab was used as a cantilever roof cover at the "Summer Theater in the Park of Culture and Leisure in Brest" (Fig. 1) and later found application as a typical project at other objects in the parks of culture of cities of the Republic of Belarus $[2,3,8]$.

The supporting nodes of the structural slab are rigidly coupled with the column heads of two types: solid - from pipes with a section of $273 \times 7 \mathrm{~mm}$ and cross-cutting 4-branchs made of pipes with a section of $102 \times 6 \mathrm{~mm}$.

The nodes of the upper and lower chords of the structure are connected by braces. All rods of the supporting space system have the same nominal length and consist of electrically welded pipes, into the ends of which round nuts with M24 thread are welded. The rods are taken in two standard sizes: structural elements (chord and spacing) $-76 \times 4 \mathrm{~mm}$, support braces on through columns - 102x4 mm.

The forces in the bars of the structural slab were determined using mechanical strain gauges. The indicators were installed on the most loaded elements of chords and braces of the structural slab, located symmetrically to the axis of the slab. To eliminate the influence of random factors and increase the reliability of the results obtained, duplication of the placement of indicators was carried out.

To observe the deformations of the structural plate (vertical displacements of nodes), two independent measurement methods were used together: linear and angular, which made it possible to obtain results with an accuracy of $\pm 1.0 \mathrm{~mm}$ (to eliminate errors in the form of inclination and displacement of the rail heel from the spherical node marker, changing instrument height, distance measurement errors, etc.).

The test was carried out according to two loading schemes: an asymmetric load acting on the cantilever part of the structural slab, and a full load evenly distributed over the slab surface. During loading with a full load, the structural plate was held for a day to take into account the creep of the bolted joints after which the load was gradually removed. 


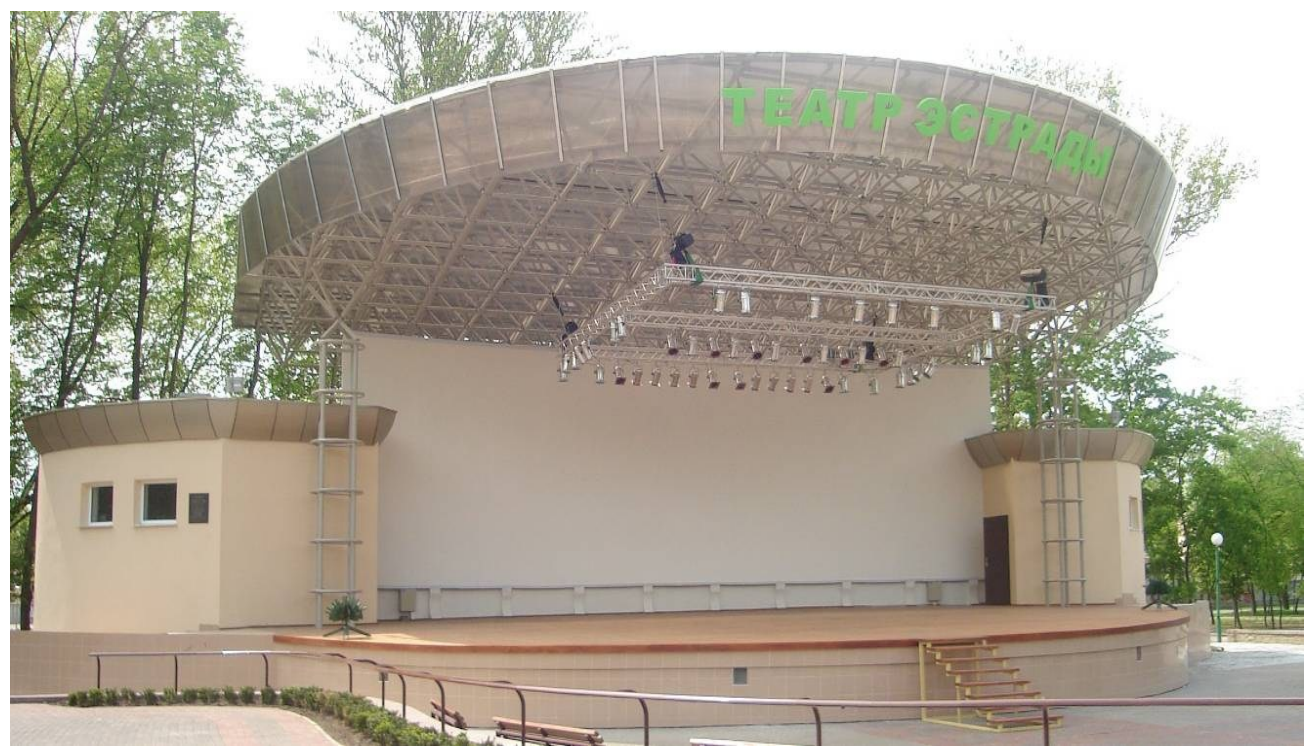

Fig. 1. General view of the structural slab in Brest.

The test load was created using concrete foundation blocks with a mass of $0.485 \mathrm{t}$, laid on wooden panels along the girders (Fig. 2) while the created level of the test nodal load was $2.495 \mathrm{kH}$, the achieved overload factor of the structure during testing was $K q=1.32$.
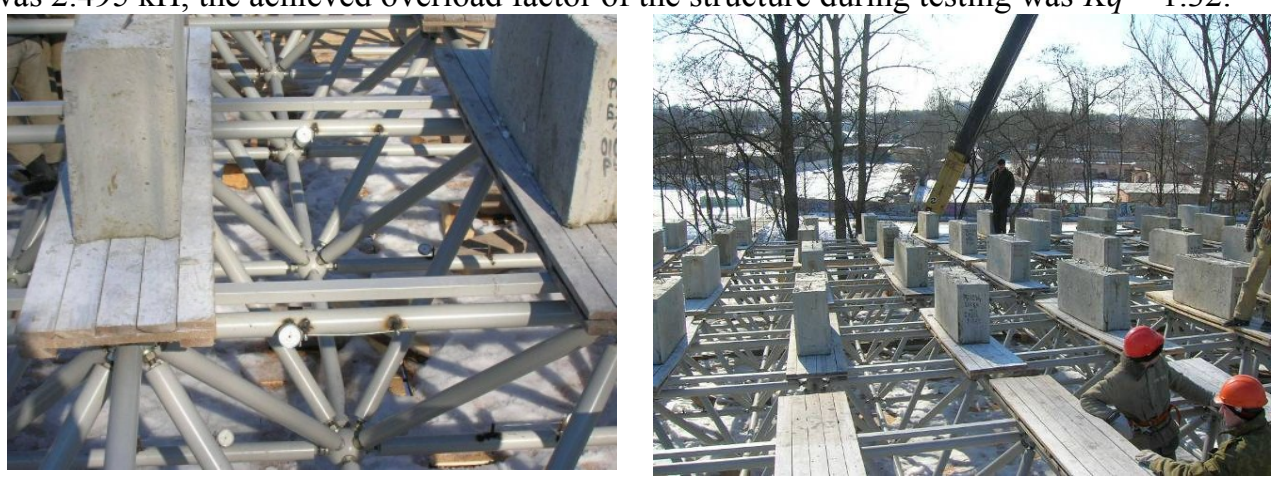

Fig.2. Testing the structural plate by static load.

The analysis of the structural slab operation was carried out both by the criterion of using the bearing capacity of all structural slab elements which was assessed using the expected coefficient of additional safety, and by the criterion of displacement deformations of the nodes of the upper belt lattice (Fig. 3).

Comparison of the results of theoretical calculations and a full-scale experiment in all the considered elements of the lattice of the structural plate shows that when the actual compliance of nodal joints is taken into account in the numerical model, there is a decrease in forces by $10-20 \%$ and deflections by $6.7 \%$. This effect is explained not only by the redistribution of forces in a statically indeterminate system but also by the real value of the compliance of nodal joints in a structural slab under conditions of a complex stress state [4]. 


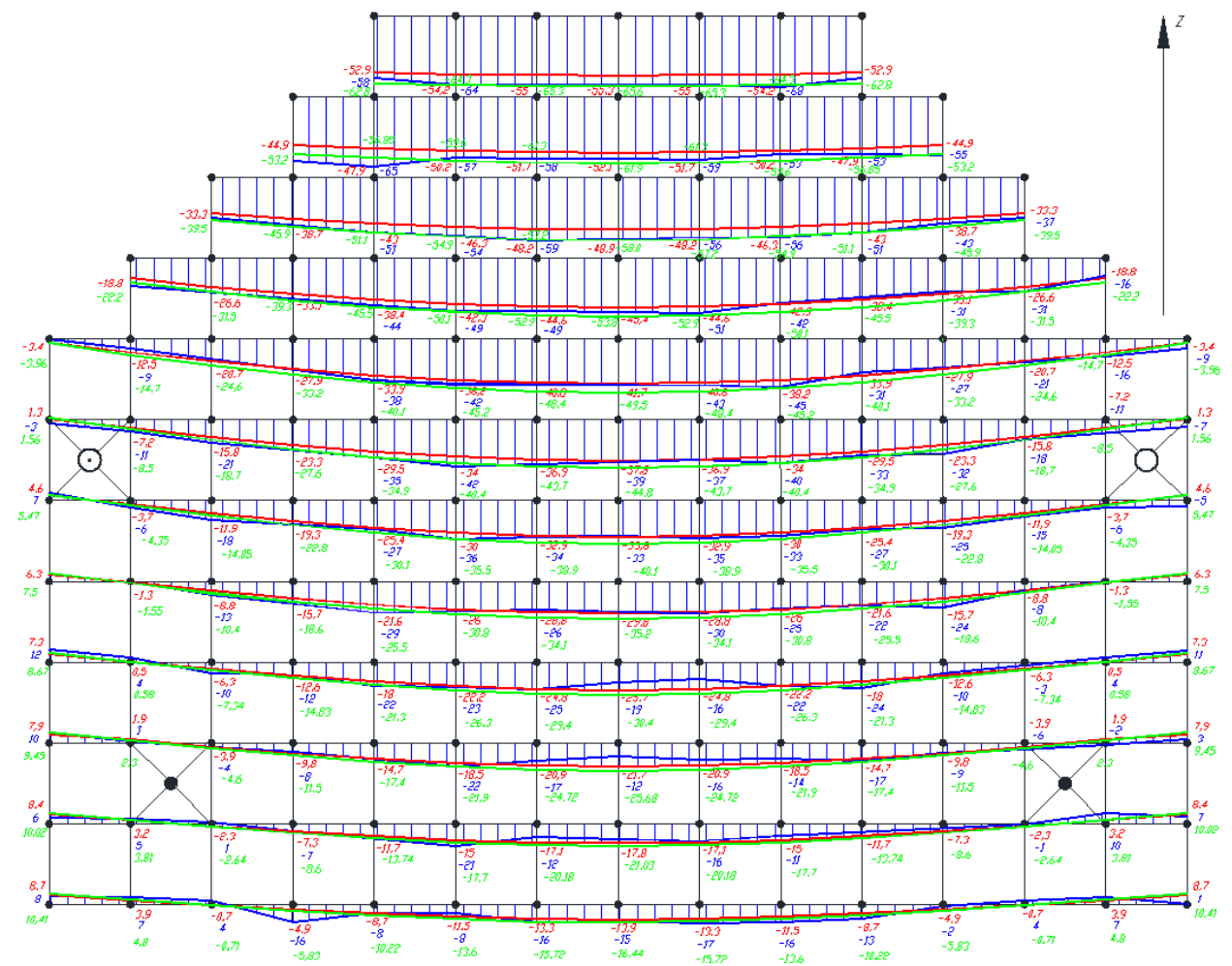

theoretical deflection without considering units compliance; experimental deflection; theoretical deflection taking into account units compliance

Fig. 3. Experimental and calculated displacements of the nodes of the lower chord of the slab.

Ice arena in Pruzhany. Large supporting construction of the structural slab in the town of Pruzhany was designed in 2005 and has an orthogonal mesh of the upper and lower chords with cells of $3.0 \times 3.0 \mathrm{~m}$ and a height of $3.0 \mathrm{~m}$ along the axes of the chords. The tilt angle of the structural board is $8^{\circ}$. The supporting nodes of the structure are hingedly coupled with the column heads. The nodes of the upper and lower chords of the structure are connected by braces. The rods are connected into a spatial structure using a nodal element of the "BrSTU" system. The structural slab includes an adjustable tightening force (Fig. 4). This roof is typical for more than five objects designed and built in the Republic of Belarus [5].

To determine the vertical displacements of the nodes of the upper chord mesh of the structural slab after laying the profiled roofing the surface was leveled along a mesh consisting of 77 control points. As a result of leveling, the geometry of roof coating was obtained which was formed after the installation of the structure and the application of its own weight of the structure, purlins and profiled roofing. Re-leveling on the same grid was performed after applying the full test load.

When modeling the stress-strain state of the roofing, taking into account the operation of the purlins and the profiled roofing, the nature of the stress state changed somewhat. The most loaded were the rods of the middle panels of the upper chord mesh. Initially, maximum compression forces were set for the third panels from the ridge. This change is quite 
natural, since the roofing located in the ridge above the central panels was not included in the work.

The discrepancies in the values of forces obtained by numerical modeling and as a result of field tests did not differ significantly - the experimental forces amounted to $86.1 \%$ $98.6 \%$ of the calculated forces. Analysis of the data showed that there was a redistribution of forces in the elements of the structural construction which is explained primarily by the high internal static uncertainty of the system as well as by some simplifications adopted in the compilation of the numerical model.

The theoretical tightening forces determined in both design models are higher than the measured forces. The inclusion of girders and profiled decking in the work allowed reducing the discrepancy in the values of the compared forces by $3.9 \%$ and $4.4 \%$.
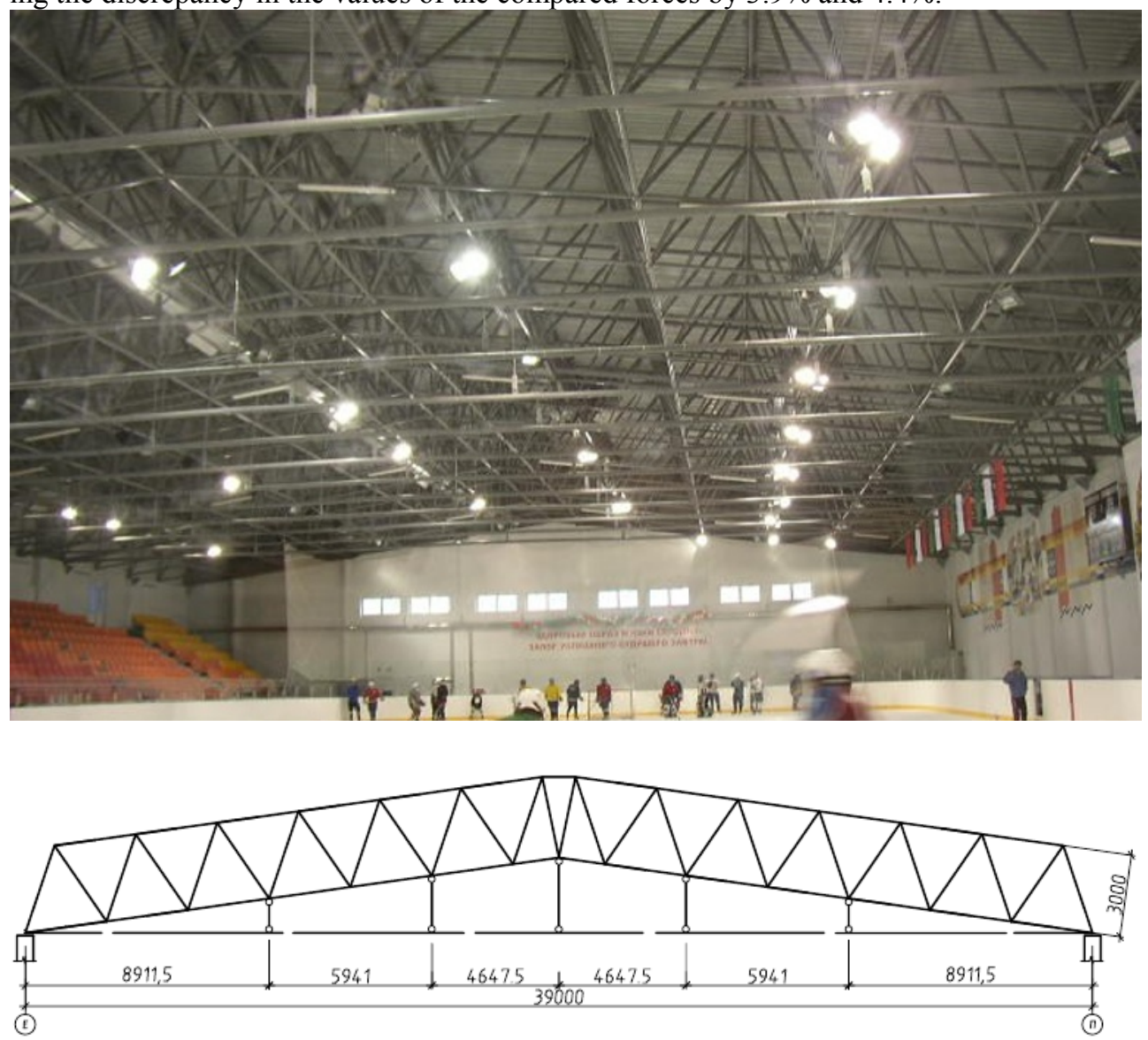

Fig.4. Ice arena in Pruzhany, general view and design.

The analysis of the deformed state of the roofing was carried out according to the diagrams of vertical displacements obtained for the nodal elements of the upper chord mesh while the theoretical displacements were determined based on the calculation in the numerical modeling of the roofing without including the girders and profiled roofing into the work of the decking. Actual displacements exceed theoretical ones by 1.3-1.6 times. There is a difference in the outlines of the diagrams in addition to differences in the magnitude of deflections. In this case, the maximum experimental deflections are not on the axis of symmetry but are shifted from it to the ends of the slap by two cells. The inclusion of pur- 
lins and gratings in the design model led to a decrease in the displacement values. The main reason for the excess of the actual deflections of constructions over the theoretical is the actual compliance of the nodal connections.

The difference between the actual stress-strain state of the roofing and the stress-strain states obtained in numerical models does not affect the bearing capacity of the roofing. High reliability of the roofing is provided by safety factors of at least 4, calculated for most of the most critical elements [5].

Roof construction of the Summer Amphitheater in Vitebsk. The roofing of the summer amphitheater was designed at the Department of Building Structures of the BrSTU in 2007. The combined system consists of a spatial rod cylindrical shell of a regular structure truncated by two inclined planes and supporting it with nine vertical arches (five lower and four upper), two inclined arches as well as two lattice columns of round tubes located behind the stands (Fig. 5).

Spatial rigidity of the roofing is provided by pinching the arches in the foundations, installing inclined arches and columns, joint work of the rod shell and all arches of the roofing. The span of the lower vertical arches is $120.014 \mathrm{~m}$, the roofing width is variable and varies from $24.0 \mathrm{~m}$ on supports to $71.0 \mathrm{~m}$ in the middle part of the roofing.

The main role in creating architectural attractiveness is assigned to the structural shell which is based on the key elements of the "BrSTU" system. The height of the shell section is $2.51 \mathrm{~m}$, the size of the cells of the upper chord mesh is $3.0 \times 3.0 \mathrm{~m}$, the lower chord mesh is $3.0 \times 2.931 \mathrm{~m}$. The construction solution of the structural shell of the roofing is given in more detail in $[5,6]$.

Testing of the structural shell of the roofing of the summer amphitheater building in Vitebsk was carried out in order to determine the actual operation and the possibility of normal operation of the roofing structures; revealing the actual stress-strain state of the roofing elements under load and determining the bearing capacity reserves under full standard load and checking the quality of manufacturing and installation of the roofing. The test load exceeded the standard value of the design load by 1.18 times (Fig. 5).

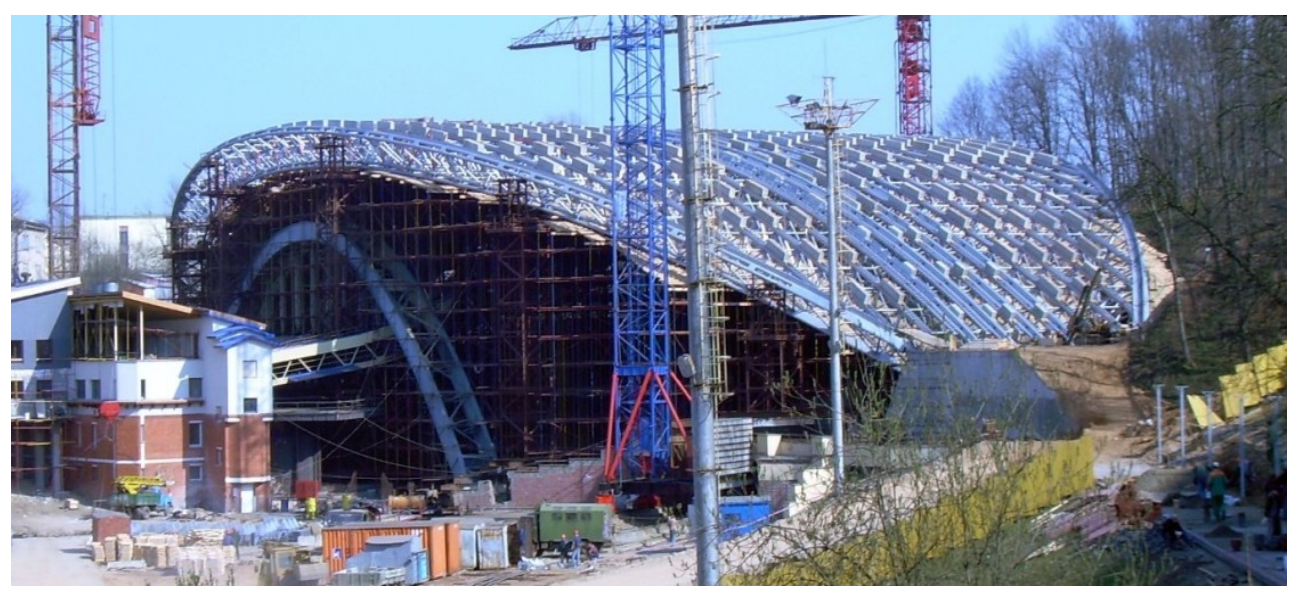

Fig.5. General view of the roof under test load.

From a comparison of the results of geodetic survey and the results of calculating a numerical model for a roofing loaded with a test load, an almost complete correspondence of the outlines of experimental and calculated (numerical) diagrams of vertical displacements of the nodes of the upper chord lattice was established (Fig. 6). 


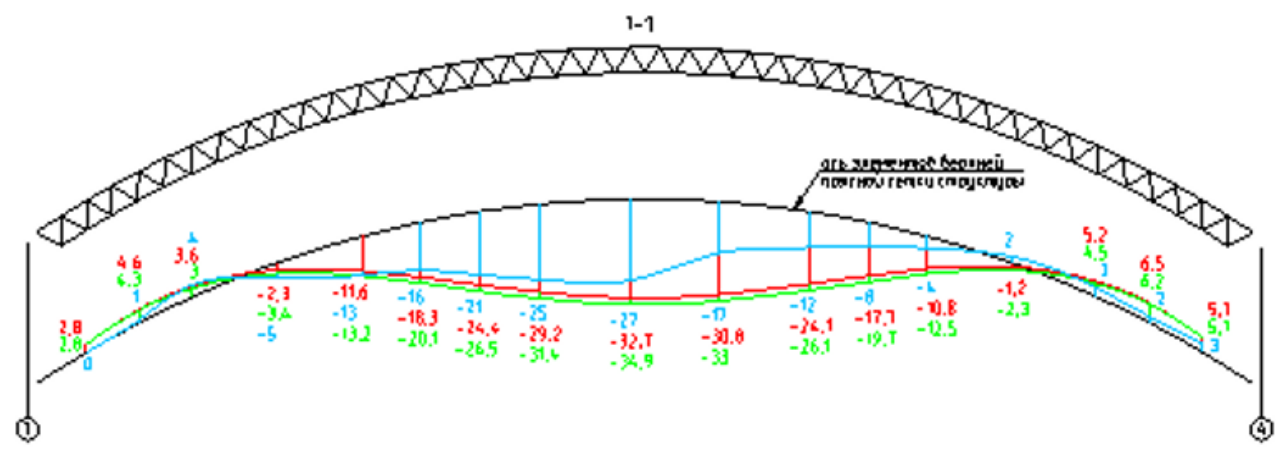

- scheme I; $\quad-\quad$ scheme II; $\quad$ test;

Fig. 6. Diagrams of vertical displacements of the nodes of the upper chord grid.

It should be noted that during the full-scale test, a significant effect of temperature on the deformation of the roofing was noted. A temperature change of $10^{\circ} \mathrm{C}$ caused additional displacements of the structural shell nodes by up to $20 \mathrm{~mm}$.

Structural shell of roofing of the ice rink in Gomel. Roofing was designed at the Department of Building Structures of the UO BrSTU in 2007. The roofing has dimensions in plan of $49.092 \times 57.82 \mathrm{~m}$ and is a combined spatial structure consisting of a structural shell and support frames with curved beams, in a longitudinal section close in outline to a sinusoid. The joining of the rods into a single structure is performed using the nodes of the "BrSTU" system (Fig. 7).

When designing the roofing some questions arose that went beyond the regulatory documents in force on the territory of the Republic of Belarus. The complexity of the geometrical surface of the shell did not allow to accept the normalized values and diagrams of wind and snow loads. Full-scale tests pursued the following goals: experimental assessment of the structural bearing capacity reserves; confirmation of the safety, functional suitability and durability of the structure; based on the data of the results of experimental studies, verification of the calculation model, to assess the accuracy of the calculation methodology and the accepted calculation assumptions; assessment of the effect of joint work of girders and structural construction on the stress-strain state of the roofing.

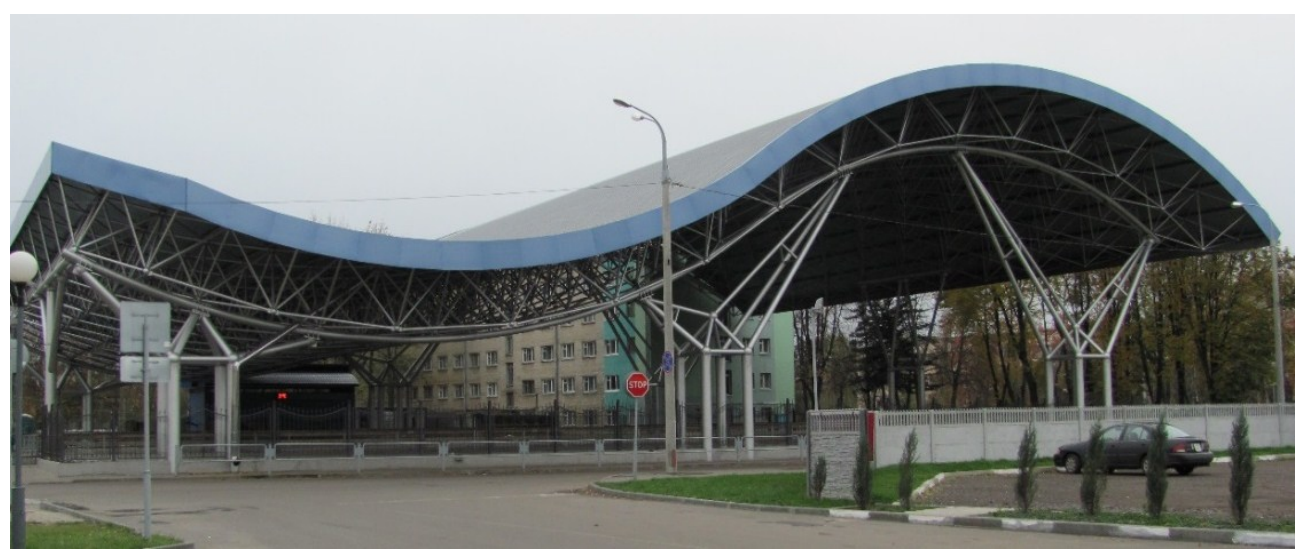

Fig. 7. General view of the ice rink roof in Gomel. 
The structural shell rests with the lower nodes on the support platforms of the composite beams to reduce the construction height of the roof and the consumption of metal.

Numerical analysis of the stress-strain state of the structural slab was carried out taking into account the experimental load acting on it. The obtained numerical values of the forces with and without taking into account the malleability of the nodal connections have a sufficiently high convergence. The largest deviation in the results is no more than $5 \%$ which indicates the high accuracy of the numerical model adopted in the calculations. The experimental forces in the most loaded rods of the lower chord of the structural slab are less than the calculated values by $11.8 \%$, and in the least loaded ones - by $9.2 \%$ (Fig. 8). $a_{n}=1,6 \mathrm{k} \sqcap a \quad \mu=2$
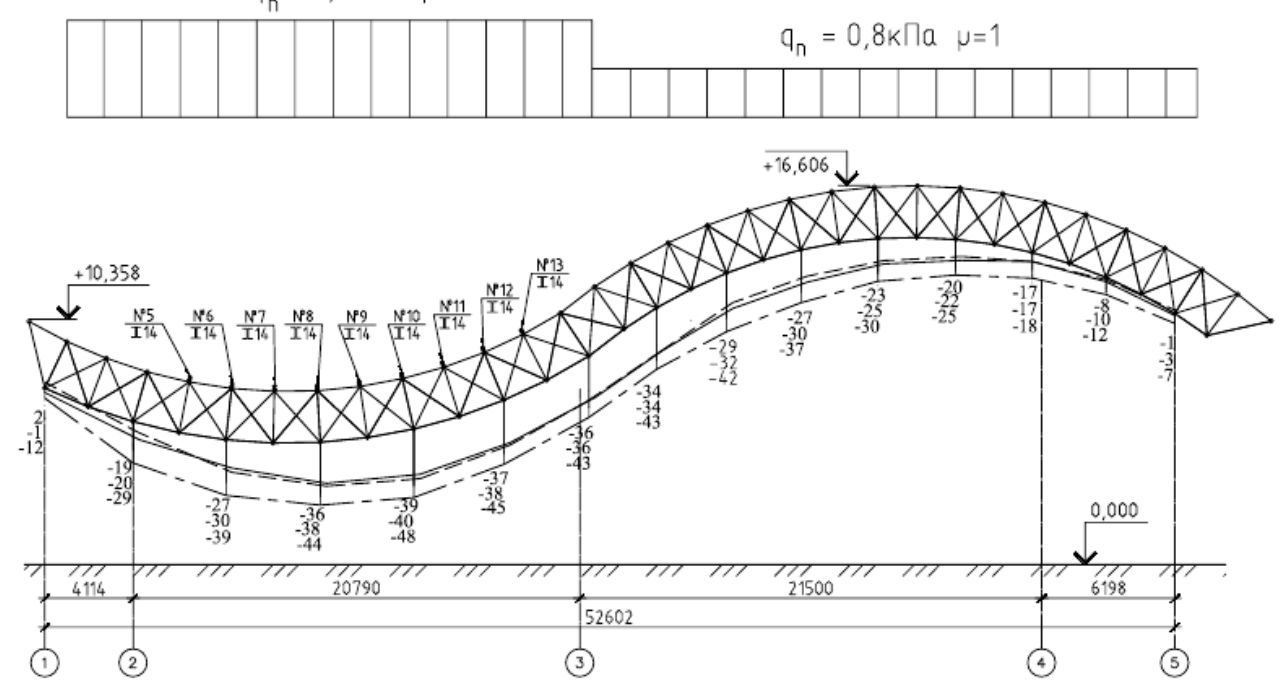

Fig. 8. Scheme of loading the roof with a test load and diagrams of vertical displacements of the nodes of the lower chord mesh.

As a result of full-scale tests, it was found that the diagrams of vertical displacements of the lower nodes of the structural shell under load, constructed from the results of measurements, repeat the outline of the diagrams obtained as a result of static calculation. The experimental displacement values are more consistent with the finite element numerical model that takes into account the work of the runs as part of the roof (Fig. 8).

Experimental studies have also confirmed that an increase in the rigidity of the upper chord of the structural shell by including the girders in the work of roofing leads to a redistribution of internal forces in the structure. Location of girders along the diagonal of the shell cell across the span made it possible to unload the central part of the upper belt of the roof on average up to $20 \%$.

\section{Conclusions}

The specialists of the Department of Building Structures have accumulated significant experience in field testing of large-span combined structural constructions. As a result of fullscale tests of objects with key elements of the "BrSTU" system, an assessment of the bearing capacity and reliability of structural constructions was made on the basis of an experimental determination of their stress-strain state. The adopted computational models are 
verified against the background of the results of experimental studies to correct their computational schemes in numerical simulation.

Analysis of the stress-strain state of structural elements showed that under conditions of complex loading, the picture of the stress-strain state of the nodal joint changes sharply, namely, its work becomes tougher. Taking into account the fact that according to the design features of the assembly the structural plate and bolted joints are initially included in the work (fixed value of the interference) in the end a favorable situation develops for reducing the overall value of the nodal joint compliance. As a result, a redistribution of forces occurs in the structure which we observed during tests and which, ultimately, has a beneficial effect on the operation of the structure as a whole.

In the course of field tests of the structural construction with new nodes, it was found that the bearing capacity of the rod elements of the metal structural plate of the roof is ensured. The average value of the additional safety factor was higher than that established in the studies of the overload factor and amounted to at least 1.50, which allows us to assert a high degree of reliability of the operation of the nodal and rod elements as well as the structure as a whole.

\section{References}

1. EN 1990-2011. Eurokod 0. Basis of Structural Design (2011)

2. V.I. Dragan, A.B. Shuryn, M.M. Shalabyta, Promyshlennoe i grazhdanskoe stroitel'stvo [Industrial and Civil Engineering], 6. Stress-Strain State of a Nodal Element of the «BrSTU» Structural Construction System. pp. 39-44 (2017)

3. M.M. Shalabyta, Napryazhenno-deformirovannoe sostoyanie uzla iz pologo shara novoj metalliche-skoj strukturnoj konstrukcii. Avtoref. dis. ... kand. tekhn. nauk: 05.23.01; BrGTU. 24 (2009)

4. V.I. Dragan, A.B. Shuryn, M.M. Shalabyta, Promyshlennoe i grazhdanskoe stroitel'stvo. 6. Napryazhenno-deformirovannoe sostoyanie uzlovogo elementa strukturnoj konstrukcii sistemy «BrGTU», pp. 39-44 (2017)

5. A.B. Shuryn, M.M. Shalabyta, Budownictwo o zoptymalizowanym potencjale energetycznym: praca zbiorova. Issledovanie dejstvitel'noj raboty bol'sheproletnogo kombinirovan-nogo strukturnogo pokrytiya s uchetom podatlivosti uzlovyh soedinenij. pp. 290-296 (2010)

6. V.I. Dragan, M.M. Shalabyta, A.V. Muhin, A.B. Shuryn. I.V. Zinkevich. Novaya metallicheskaya strukturnaya konstrukciya sistemy «BrGTU». Opyt proektirovaniya, issledovanij i stroitel'stva v Respublike Belarus'. Promyshlennoe i grazhdanskoe stroitel'stvo v sovremennyh usloviyah : sb. nauch. tr. Mezhdunar. nauchn.-tekhn. konferencii, Moskva, 19-21 aprelya 2011. pp. 34-37 (2011)

7. V.I. Dragan, A.B. Shuryn, A.V. Muhin, M.M. Shalabyta, Kombinirovannaya strukturnaya obolochka pokrytiya ledovogo katka po ul. Golovackogo v g. Gomele. Perspektivy razvitiya novyh tekhnologij v stroitel'stve i pod-gotovke kadrov Respubliki Belarus' : sb. tr. XVIII mezhdunar. nauchn.-metod. seminara : v 2-h t. pod obshch. T.I, pp. 53-59 (2012)

8. M.M. Shalabyta, T.P., Shalobyta. Budownictwo o zoptymalizo-wanym potencjale energetycznym: praca zbiorova. Napryazhenno-deformirovannoe sostoyanie i metodika rascheta na proch-nost' uzla soedineniya sterzhnevyh elementov metallicheskih strukturnyh konstrukcij tipa «BrGTU», pp. 279-290 (2010) 